\title{
Two New Indolopyridoquinazoline Alkaloidal Glycosides from Ranunculus ternatus
}

\author{
Lin Zhang, Zhuang YANG, and Jing-Kui TIAN* \\ Institute of Modern Traditional Chinese Medicine, College of Pharmaceutical Sciences, Zhejiang University; Hangzhou \\ 310058, China. Received March 8, 2007; accepted April 24, 2007
}

\begin{abstract}
Two new indolopyridoquinazoline alkaloidal glycosides, 11- $O$ - $\beta$-D-glucopyranosyl rutaecarpine (ternatoside C) and 11- $O$ - $\alpha$-L-rhamnosyl- $(1 \rightarrow 6)$ - $\beta$-D-glucopyranosyl rutaecarpine (ternatoside $D)$ were isolated from the roots of Ranunculus ternatus. Their structures were determined on the basis of spectroscopic and chemical methods.
\end{abstract}

Key words Ranunculus ternatus; indolopyridoquinazoline alkaloid; ternatoside C; ternatoside D

Ranunculus ternatus THUNB. is a plant belonging to the Ranunculaceae family and is widely distributed in the Henan region of China. The root of $R$. ternatus is used by traditional practitioners as a treatment for tuberculosis ${ }^{1)}$ and its ethanol extract has exhibited obviously antituberculosis activities. ${ }^{2}$ To investigate the bioactive antituberculosis constituents present, we have undertaken systematic chemical and pharmaceutical research work on this plant. About 20 compounds have been isolated from the roots of $R$. ternatus, including some fatty acid esters, 5-hydroxymethyl furoic acid and four glycosides. ${ }^{3-7)}$ Further research has led to two more new indolopyridoquinazoline alkaloidal glucosides, compound $\mathbf{1}$ (ternatoside C) and compound $\mathbf{2}$ (ternatoside D) from this plant, and alkaloidal glycoside compounds are reported for the first time to be obtained from Ranunculus genus. In this paper, we report the isolation and structural elucidation of these two compounds on the basis of spectroscopic and chemical methods.

\section{Results and Discussion}

The ethanolic extract of the dried roots was evaporated in vacuo, and then the residue was suspended in $\mathrm{H}_{2} \mathrm{O}$ and the $\mathrm{H}_{2} \mathrm{O}$ soluble part was submitted to $\mathrm{D}_{101}$ macroporous resin column chromatography. The $75 \%$ ethanol elutant from the $\mathrm{D}_{101}$ macroporous resin column was separated by a combination of silica gel and Sephadex LH-20 column chromatography which led to two new alkaloidal glycoside compounds $\mathbf{1}$ and 2.

Compound 1 was obtained as a brown powder, mp 185 $187^{\circ} \mathrm{C}$, and reacted positively to the Dragendorff reagent. The positive ion HR-FAB-MS gave a quasi-molecular ion peak at $\mathrm{m} / \mathrm{z} 466.1551\left([\mathrm{M}+\mathrm{H}]^{+}\right.$, Calcd 466.1614) corresponding to the molecular formula of $\mathrm{C}_{24} \mathrm{H}_{23} \mathrm{~N}_{3} \mathrm{O}_{7}$. The positive ESI-MS gave a fragment at $m / z 304\left([\mathrm{M}+\mathrm{H}-162]^{+}\right)$besides a quasi-molecular ion at $m / z 466\left([\mathrm{M}+\mathrm{H}]^{+}\right)$, indicating the potential presence of one hexose unit.

The UV spectrum showed $\lambda_{\max }(\mathrm{MeOH})(\log \varepsilon)$ at 222 (4.61) and 353 (4.86) $\mathrm{nm}$, which suggested the existence of a conjugated structure (alkaloid aglycone) in compound $\mathbf{1}$, and the absorption of IR spectrum at $1690 \mathrm{~cm}^{-1}$ showed the existence of a conjugated carbonyl group.

The ${ }^{1} \mathrm{H}-\mathrm{NMR}$ spectrum of $\mathbf{1}$ revealed two series of aromatic proton systems, including three protons of an ABX system at $\delta 7.39(1 \mathrm{H}, \mathrm{d}, J=8.8 \mathrm{~Hz}, \mathrm{H}-9), 7.03(1 \mathrm{H}, \mathrm{dd}, J=$ $8.8,2.2 \mathrm{~Hz}, \mathrm{H}-10)$ and $7.24(1 \mathrm{H}, \mathrm{d}, J=2.2 \mathrm{~Hz}, \mathrm{H}-12)$, and four protons of a 1,2-substituted aromatic ring at $\delta 7.48$
8.17; and a downfield proton at $\delta 11.72(1 \mathrm{H}, \mathrm{s}, \mathrm{H}-13)$. These signal patterns were similar to those of the quinazolinocarboline alkaloid 11-hydroxyrutaecarpine. ${ }^{8)}$ The ${ }^{13} \mathrm{C}-\mathrm{NMR}$ spectrum of 1 gave signals of a carbonyl group at $\delta 160.6,15 s p^{2}$ carbon signals and two carbon signals at $\delta 40.9$ and 18.9, which indicated that the carbon signals of the aglycone moiety were also similar to those of rutaecarpine, ${ }^{9)}$ except for those signals due to $\mathrm{C}-11, \mathrm{C}-10$ and $\mathrm{C}-12$. Further assignments of all hydrogen and carbon signals were achieved by its HMQC, ${ }^{1} \mathrm{H}-{ }^{1} \mathrm{H}$ COSY, DEPT and HMBC spectra (Table 1). The above evidence indicates the aglycone of compound 1 was 11-hydroxyrutaecarpine. The existence of an imine moiety could be further confirmed by the $\mathrm{HMBC}$ and ${ }^{1} \mathrm{H}-{ }^{1} \mathrm{H}$ COSY spectra. In the HMBC spectrum of $\mathbf{1}$, the correlations between $\delta_{\mathrm{C}} 160.6(\mathrm{C}-5)$ and $\delta_{\mathrm{H}} 8.17(\mathrm{H}-4), \delta_{\mathrm{H}} 4.46(\mathrm{H}-7)$ could be observed, respectively, while the ${ }^{1} \mathrm{H}-{ }^{1} \mathrm{H}$ COSY spectrum displayed a correlation between $\delta_{\mathrm{H}} 4.46(\mathrm{H}-7)$ and $\delta_{\mathrm{H}} 3.14(\mathrm{H}-8)$. The HMBC spectrum also displayed correlations between $\delta_{\mathrm{H}} 11.72(\mathrm{H}-13)$ and $\delta_{\mathrm{C}} 117.6(\mathrm{C}-8 \mathrm{a}), \delta_{\mathrm{C}}$ $125.0(\mathrm{C}-8 \mathrm{~b}), \delta_{\mathrm{C}} 105.2(\mathrm{C}-12), \delta_{\mathrm{C}} 134.7(\mathrm{C}-12 \mathrm{a}), \delta_{\mathrm{C}} 127.7$ $(\mathrm{C}-13 \mathrm{a})$ and $\delta_{\mathrm{C}} 145.3(\mathrm{C}-13 \mathrm{~b})$, which were also indicative of the presence of a rutaecarpine-type aglycone.

Moreover, the ${ }^{1} \mathrm{H}$ - and ${ }^{13} \mathrm{C}-\mathrm{NMR}$ spectra of $\mathbf{1}$ gave a set of signals of one hexose group: an anomeric proton signal at $\delta_{\mathrm{H}}$ $4.78(1 \mathrm{H}, \mathrm{d}, J=7.2 \mathrm{~Hz})$, the other 6 proton signals at $\delta$ $3.26-3.88$, and six carbon signals including the anomeric carbon signal at $\delta_{\mathrm{C}} 102(\mathrm{C}-1)$ and another 5 carbon signals at $\delta_{\mathrm{C}} 62-76$. The hexose was suggested to be a D-glucose by the comparison of ${ }^{13} \mathrm{C}-\mathrm{NMR}$ data with those reported in the literature $^{10)}$ and confirmed by GC analysis after the acid hydrolysis and preparation of its thiazolidine derivative. ${ }^{11)}$ The coupling constant of $\mathrm{H}-1^{\prime}\left(\delta_{\mathrm{H}} 4.78, \mathrm{~d}, J=7.2 \mathrm{~Hz}\right)$ indicated the $\mathrm{D}$-glucose was a $\beta$-linkage. Compared with the ${ }^{13} \mathrm{C}$-NMR data of 11-hydroxyrutaecarpine, the chemical shift of C-11 had shifted downfield for $27.8 \mathrm{ppm}$ while the chemical shifts of $\mathrm{C}-10$ and $\mathrm{C}-12$ had shifted upfield for 6.3 and $6.9 \mathrm{ppm}$, respectively, which suggested that $\mathrm{C}-11$ of 1 should be glycosylated. The HMBC correlation achieved between the anomeric proton at $\delta_{\mathrm{H}} 4.78\left(\mathrm{H}-1^{\prime}\right)$ and $\mathrm{C}-11\left(\delta_{\mathrm{C}} 151.9\right)$ also supported a $\mathrm{C}-11$ location for the sugar unit.

Thus, the structure of compound 1 was established as 11$O$ - $\beta$-D-glucopyranosyl rutaecarpine, and it was named ternatoside $\mathrm{C}$ (Fig. 1 ).

Compound 2 was obtained as a brown powder, mp 172 $175^{\circ} \mathrm{C}$, and also gave a positive result to Dragendorff's reagent. Its molecular formula was determined to be 
Table 1. ${ }^{1} \mathrm{H}-(500 \mathrm{MHz})$ and ${ }^{13} \mathrm{C}-\mathrm{NMR}(125 \mathrm{MHz})$ Spectroscopic Data of $\mathbf{1}$ and $\mathbf{2}$ in DMSO- $d_{6}$

\begin{tabular}{|c|c|c|c|c|c|}
\hline \multirow{2}{*}{ Position } & \multicolumn{2}{|l|}{1} & \multirow{2}{*}{ Position } & \multicolumn{2}{|l|}{2} \\
\hline & $\delta_{\mathrm{H}}$ & $\delta_{\mathrm{C}}$ & & $\delta_{\mathrm{H}}$ & $\delta_{\mathrm{C}}$ \\
\hline 1 & $7.68(\mathrm{~d}, 1 \mathrm{H}, 7.8)$ & 126.4 & 1 & $7.63(\mathrm{~d}, 1 \mathrm{H}, 7.8)$ & 126.1 \\
\hline 2 & $7.82(\mathrm{dt}, 1 \mathrm{H}, 7.8,1.4)$ & 134.3 & 2 & $7.77(\mathrm{dt}, 1 \mathrm{H}, 7.8,1.4)$ & 134.0 \\
\hline 3 & $7.48(\mathrm{dt}, 1 \mathrm{H}, 7.8,1.4)$ & 125.9 & 3 & $7.43(\mathrm{dt}, 1 \mathrm{H}, 7.8,1.4)$ & 125.5 \\
\hline 4 & $8.17(\mathrm{dd}, 1 \mathrm{H}, 7.8,1.4)$ & 126.5 & 4 & $8.14(\mathrm{dd}, 1 \mathrm{H}, 7.8,1.4)$ & 126.1 \\
\hline $4 a$ & & 120.6 & $4 a$ & & 120.4 \\
\hline 5 & & 160.6 & 5 & & 160.1 \\
\hline 7 & $4.46(\mathrm{~m}, 2 \mathrm{H})$ & 40.9 & 7 & $4.46(\mathrm{~m}, 2 \mathrm{H})$ & 40.5 \\
\hline 8 & $3.14(\mathrm{~m}, 2 \mathrm{H})$ & 18.9 & 8 & $3.13(\mathrm{~m}, 2 \mathrm{H})$ & 18.6 \\
\hline $8 \mathrm{a}$ & & 117.6 & $8 \mathrm{a}$ & & 117.1 \\
\hline $8 \mathrm{~b}$ & & 125.0 & $8 \mathrm{~b}$ & & 124.7 \\
\hline 9 & $7.39(\mathrm{~d}, 1 \mathrm{H}, 8.8)$ & 117.2 & 9 & $7.37(\mathrm{~d}, 1 \mathrm{H}, 8.8)$ & 117.0 \\
\hline 10 & $7.03(\mathrm{dd}, 1 \mathrm{H}, 8.8,2.2)$ & 113.0 & 10 & $7.01(\mathrm{dd}, 1 \mathrm{H}, 8.8,2.2)$ & 112.3 \\
\hline 11 & & 151.9 & 11 & & 151.5 \\
\hline 12 & $7.24(\mathrm{~d}, 1 \mathrm{H}, 2.2)$ & 105.2 & 12 & $7.26(\mathrm{~d}, 1 \mathrm{H}, 2.2)$ & 105.0 \\
\hline $12 \mathrm{a}$ & & 134.7 & $12 \mathrm{a}$ & & 134.2 \\
\hline 13 & $11.72(\mathrm{~s})$ & & 13 & $11.76(\mathrm{~s})$ & \\
\hline $13 \mathrm{a}$ & & 127.7 & $13 \mathrm{a}$ & & 127.7 \\
\hline $13 b$ & & 145.3 & $13 b$ & & 144.9 \\
\hline $14 \mathrm{a}$ & & 147.3 & $14 \mathrm{a}$ & & 147.0 \\
\hline $1^{\prime}$ & $4.78(\mathrm{~d}, 1 \mathrm{H}, 7.2)$ & 102.0 & $1^{\prime}$ & $4.73(\mathrm{~d}, 1 \mathrm{H}, 7.2)$ & 102.5 \\
\hline $2^{\prime}$ & $3.26(\mathrm{~m}, 1 \mathrm{H})$ & 73.3 & $2^{\prime}$ & $3.27(\mathrm{~m}, 1 \mathrm{H})$ & 73.6 \\
\hline $3^{\prime}$ & $3.28(\mathrm{~m}, 1 \mathrm{H})$ & 76.5 & $3^{\prime}$ & $3.24(\mathrm{~m}, 1 \mathrm{H})$ & 76.0 \\
\hline $4^{\prime}$ & $3.10(\mathrm{~m}, 1 \mathrm{H})$ & 70.1 & $4^{\prime}$ & $3.15(\mathrm{~m}, 1 \mathrm{H})$ & 70.4 \\
\hline $5^{\prime}$ & $3.43(\mathrm{~m}, 1 \mathrm{H})$ & 76.3 & $5^{\prime}$ & $3.49(\mathrm{~m}, 1 \mathrm{H})$ & 75.5 \\
\hline $6^{\prime}$ & $3.32(\mathrm{dd}, 1 \mathrm{H}, 7.8,14.0)$ & 62.1 & $6^{\prime}$ & $3.46(\mathrm{dd}, 1 \mathrm{H}, 7.5,13.5)$ & 66.1 \\
\hline & $3.88(\mathrm{dd}, 1 \mathrm{H}, 7.8,14.0)$ & & & $3.95(\mathrm{dd}, 1 \mathrm{H}, 7.5,13.5)$ & \\
\hline $1^{\prime \prime}$ & & & $1^{\prime \prime}$ & $4.58(\mathrm{~d}, 1 \mathrm{H}, 5.5)$ & 100.5 \\
\hline $2^{\prime \prime}$ & & & $2^{\prime \prime}$ & $3.65(\mathrm{~m}, 1 \mathrm{H})$ & 70.4 \\
\hline $3^{\prime \prime}$ & & & $3^{\prime \prime}$ & $3.51(\mathrm{~m}, 1 \mathrm{H})$ & 70.8 \\
\hline $4^{\prime \prime}$ & & & $4^{\prime \prime}$ & $3.20(\mathrm{~m}, 1 \mathrm{H})$ & 72.1 \\
\hline $5^{\prime \prime}$ & & & $5^{\prime \prime}$ & $3.47(\mathrm{~m}, 1 \mathrm{H})$ & 68.3 \\
\hline $6^{\prime \prime}$ & & & $6^{\prime \prime}$ & $1.13(\mathrm{~d}, 3 \mathrm{H}, 6.2)$ & 17.8 \\
\hline
\end{tabular}

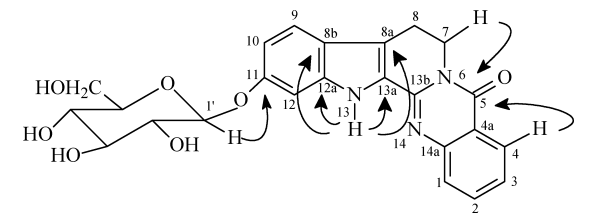

Fig. 1. Key HMBC Correlations of Compound $\mathbf{1}$

$\mathrm{C}_{30} \mathrm{H}_{33} \mathrm{O}_{11} \mathrm{~N}_{3}$ by HR-FAB-MS m/z 612.2188 [M+H] ${ }^{+}$(Calcd for $\mathrm{C}_{30} \mathrm{H}_{34} \mathrm{O}_{11} \mathrm{~N}_{3}, 612.2161$ ). The fragment ion peaks of ESI$\mathrm{MS}$ at $\mathrm{m} / \mathrm{z} 466[\mathrm{M}+\mathrm{H}-146]^{+}$and $304[\mathrm{M}+\mathrm{H}-146-162]^{+}$ indicated the presences of a hexose unit and another terminal pentose, 146 Da more than that of compound 1.

The UV spectrum of compound 2 showed $\lambda_{\max }(\mathrm{MeOH})$ $(\log \varepsilon)$ at $220(4.51)$ and $351(4.88) \mathrm{nm}$, gave the same conjugated alkaloid aglycone as that of compound 1 . IR spectrum of $\mathbf{2}$ also displayed an absorption band of a conjugated carbonyl group at $1690 \mathrm{~cm}^{-1}$.

The NMR data of $\mathbf{2}$ resembled those of $\mathbf{1}$ except $\mathbf{2}$ had one more pentose unit than compound 1 (Table 1). These two sugar units were proved to be a D-glucose and an L-rhamnose respectively by comparing their ${ }^{13} \mathrm{C}-\mathrm{NMR}$ data with those reported in the literature, ${ }^{10,12}$ and were confirmed by GC analysis after the acid hydrolysis and preparation of their thiazolidine derivatives. ${ }^{11)}$ The coupling constant of $\mathrm{H}-1^{\prime}\left(\delta_{\mathrm{H}}\right.$ $4.73, \mathrm{~d}, J=7.2 \mathrm{~Hz}$ ) indicated the D-glucose was a $\beta$-linkage while the coupling constant of $\mathrm{H}-1^{\prime \prime}(4.58, \mathrm{~d}, J=5.5 \mathrm{~Hz})$ indi-

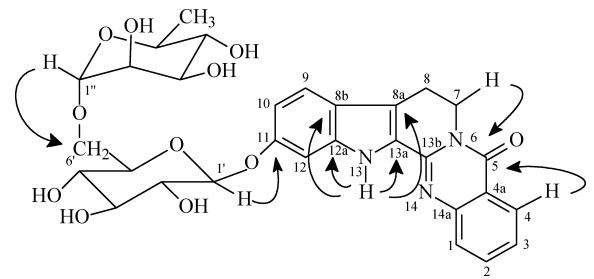

Fig. 2. Key HMBC Correlations of Compound 2

cated the L-rhamnose was an $\alpha$-linkage. The sugar sequences and the location of the disaccharide chain were determined by comparison with the NMR signals of $\mathbf{1}$. The correlations between the anomeric proton of glucose at $\delta_{\mathrm{H}} 4.73\left(\mathrm{H}-1^{\prime}\right)$ and $\mathrm{C}-11$ of aglycone at $\delta_{\mathrm{C}} 151.5$, and the anomeric proton of rhamnose at $\delta_{\mathrm{H}} 4.58\left(\mathrm{H}-1^{\prime \prime}\right)$ and C- $6^{\prime}$ of glucose at $\delta_{\mathrm{C}} 66.1$ could also be observed in the HMBC spectrum of 2 , which further confirmed the sugar sequences of the disaccharide chain.

Therefore, the structure of 2 was elucidated as 11-O- $\alpha$ L-rhamnosyl-( $1 \rightarrow 6)-\beta$-D-glucopyranosyl rutaecarpine, and named ternatoside D (Fig. 2).

Assignment of all the NMR signals of compound $\mathbf{2}$ was achieved through a combination of ${ }^{1} \mathrm{H}-{ }^{1} \mathrm{HCOSY}$, HMQC, DEPT, HMBC experiments (Table 1).

Rutaecarpine is a main quinazolinocarboline alkaloid isolated from Evodia rutaecapa, a famous traditional Chinese 
medicine, and shows a variety of pharmacological effects including antithrombotic and vasorelaxant effects. ${ }^{13)}$ Ueng et al. reported recently that 11-hydroxyrutaecarpine was one of the oxidation metabolites of rutaecarpine by liver microsomal enzymes in rats. ${ }^{8)}$ In general, xenobiotic hydroxylation metabolites have higher hydrophilicity than their parent compounds and show less biological activities or toxicities. It is clear that compounds $\mathbf{1}$ and $\mathbf{2}$ with more glycosyl than 11-hydroxyrutaecarpine showed higher hydrophilicity. Thus, further studies on the pharmacological and toxicological effects of compounds $\mathbf{1}$ and $\mathbf{2}$ are needed before clinical application.

\section{Experimental}

General Melting points were measured on a Fisher-Johns apparatus and were uncorrected. IR spectra were recorded on a Perkin-Elmer $983 \mathrm{G}$ spectrometer. One- and two-dimensional NMR spectra were recorded on a Bruker 500 spectrometer. The ESI-MS and HR-ESI-MS were recorded in a LCQ DECA XP plus spectrometer. GC-MS was performed using a SHIMADZU QP5050A. Thin-layer chromatography employed precoated Silica gel plates (Qingdao Haiyang). For column chromatography, silica gel (200300 mesh, Qingdao Haiyang), $\mathrm{D}_{101}$ macroporous resin (Tianjin Nankai) and Sephadex LH-20 (Pharmacia) were used. TLC (silica gel $\mathrm{GF}_{254}$ precoated plates, Qingdao Haiyang) detections were obtained by spraying $10 \% \mathrm{H}_{2} \mathrm{SO}_{4}$ following heating.

Materials The roots of Ranunculus ternatus were collected in Henan province of China and identified by Dr. Lin Zhang, Institute of Modern Traditional Chinese Medicine, College of Pharmaceutical Sciences, Zhejiang University, in which the voucher specimen (HN-05-0805) is deposited.

Extraction and Isolation The dried plant materials $(10 \mathrm{~kg})$ were ground and extracted with $95 \% \mathrm{EtOH}$ twice and then with $50 \% \mathrm{EtOH}$ twice under reflux. The $95 \% \mathrm{EtOH}$ extract and 50\% EtOH extract were combined, and then concentrated in vacuo. The concentrates were dissolved in $\mathrm{H}_{2} \mathrm{O}$ and then the $\mathrm{H}_{2} \mathrm{O}$ soluble part was run on a $\mathrm{D}_{101}$ macroporous resin column and eluted with water, $25 \% \mathrm{EtOH}, 75 \% \mathrm{EtOH}$, and then $95 \% \mathrm{EtOH}$. The $75 \%$ EtOH fraction solvent was removed under reduced pressure to give the extract $(480 \mathrm{~g})$. The extract was chromatographed over silica gel, and was eluted gradiently with $\mathrm{CHCl}_{3}-\mathrm{CH}_{3} \mathrm{OH}(95: 5-40: 60)$ to give 50 fractions. Fractions $36-40\left(\mathrm{CHCl}_{3}-\mathrm{CH}_{3} \mathrm{OH}, 60: 40\right)$ were subjected to repeated column chromatography over silica gel with $\mathrm{CHCl}_{3}-\mathrm{CH}_{3} \mathrm{OH}$ and then purified on Sephadex LH-20 with $\mathrm{CH}_{3} \mathrm{OH}$ to give compounds $1(73 \mathrm{mg})$ and 2 (126 mg).

11-O- $\beta$-D-Glucopyranosyl Rutaecarpine (1): Brown powder $(\mathrm{MeOH}), \mathrm{mp}$ $185-187^{\circ} \mathrm{C}, \mathrm{UV}(\mathrm{MeOH}) \lambda_{\max }(\mathrm{nm}): 222(\log \varepsilon 4.61), 353(\log \varepsilon 4.86)$, IR $(\mathrm{KBr}) v_{\max } \mathrm{cm}^{-1}: 3420,2870,1690,1645,1475,1390,1207,1030$ ${ }^{1} \mathrm{H}-\mathrm{NMR}$ (DMSO- $d_{6}, 500 \mathrm{MHz}$ ) see Table 1 and ${ }^{13} \mathrm{C}-\mathrm{NMR}$ (DMSO- $d_{6}$, $125 \mathrm{MHz}$ ) see Table 1; positive ESI-MS $m / z 466.3[\mathrm{M}+\mathrm{H}]^{+}, 304.2[\mathrm{M}+$
$\mathrm{H}-162]^{+}$; HR-FAB-MS $m / z 466.1551[\mathrm{M}+\mathrm{H}]^{+}$(Calcd for $\mathrm{C}_{24} \mathrm{H}_{24} \mathrm{O}_{7} \mathrm{~N}_{3}$, 466.1614).

11- $O$ - $\alpha$-L-Rhamnosyl-( $1 \rightarrow 6)$ - $\beta$-D-glucopyranosyl Rutaecarpine (2): Brown powder $(\mathrm{MeOH}), \mathrm{mp} 172-175^{\circ} \mathrm{C}$, UV $(\mathrm{MeOH}) \lambda_{\max }(\mathrm{nm}): 220$ $(\log \varepsilon 4.51), 351(\log \varepsilon 4.88)$, IR (KBr) $v_{\max } \mathrm{cm}^{-1}: 3425,2870,1695,1645$, $1470,1395,1205,1025 ;{ }^{1} \mathrm{H}-\mathrm{NMR}$ (DMSO- $d_{6}, 500 \mathrm{MHz}$ ) see Table 1 and ${ }^{13} \mathrm{C}$-NMR (DMSO- $d_{6}, 125 \mathrm{MHz}$ ) see Table 1; positive ESI-MS $\mathrm{m} / \mathrm{z} 612.2$ $[\mathrm{M}+\mathrm{H}]^{+}, 466.3[\mathrm{M}+\mathrm{H}-146]^{+}, 304.1[\mathrm{M}+\mathrm{H}-146-162]^{+}$; HR-FAB-MS $m / z 612.2188[\mathrm{M}+\mathrm{H}]^{+}\left(\right.$Calcd for $\left.\mathrm{C}_{30} \mathrm{H}_{34} \mathrm{O}_{11} \mathrm{~N}_{3}, 612.2161\right)$.

Acid Hydrolysis Compounds $\mathbf{1}$ and $\mathbf{2}$ (each $5 \mathrm{mg}$ ) were dissolved in water $(100 \mathrm{ml})$ and $2 \mathrm{M} \mathrm{HCl}(100 \mathrm{ml})$ and then heated at $100^{\circ} \mathrm{C}$ for $1 \mathrm{~h}$. The mixture was then passed through an Amberlite IRA-60E column $(6 \times 50$ $\mathrm{mm}$ ) and the eluate was concentrated. The residue was dissolved in pyridine $(25 \mathrm{ml})$ and stirred with D-cysteine methyl ester $(4.0 \mathrm{mg})$ for $1.5 \mathrm{~h}$ at $60^{\circ} \mathrm{C}$. To the reaction mixture, hexamethyldisilazan $(10 \mathrm{ml})$ and trimethylsilyl chloride $(10 \mathrm{ml})$ were added and the mixture was stirred for $30 \mathrm{~min}$ at $60^{\circ} \mathrm{C}$. The supernatant was then analyzed by GC [Column: DB-50, $25 \mathrm{~mm} \times 30 \mathrm{~m}$; column temperature: $235^{\circ} \mathrm{C}$; carrier gas: $\mathrm{N}_{2}$; retention time: $\mathrm{D}-\mathrm{Glc}(16.5 \mathrm{~min})$, L-Glc $(16.1 \mathrm{~min})$, D-Rha $(13.2 \mathrm{~min})$, L-Rha $(12.9 \mathrm{~min})$. D-Glucose and Lrhamnose were detected from the new compound.

Acknowledgments This research was supported by the National Natural Science Foundation of China (Grant No. 30400584).

\section{References}

1) Zhu S. H., "Commercial Science of Chinese Medical Materials," 1st ed., People Healthy Publishing House, Beijing, China, 1990, p. 212.

2) Lu X. F.. Lishizhen Med. Mater. Med. Res., 16, 1046-1047 (2005).

3) Tian J. K., Wu L. M., Wang A. W., Liu H. M., Geng H., Wang M., Deng L. Q., J. Chin. Pharm., 39, 661-662 (2004).

4) Yun C., Tian J. K., Cheng Y. Y., J. Chin. Pharm., 40, 1373-1375 (2005).

5) Zhang X. G., Tian J. K., J. Chin. Pharm., 41, 1460-1461 (2006).

6) Tian J. K., Sun F., Cheng Y. Y., Chin. Chem. Lett., 16, 928-930 (2005).

7) Tian J. K., Sun F., Cheng Y. Y., J. Asian Nat. Prod. Res., 8, 35-39 (2006).

8) Ueng Y. F., Yu H. J., Lee C. H., Peng C., Jan W. C., Ho L. K., Chen C. F., Don M. J., J. Chromatogr. A, 1076, 103-109 (2005).

9) Bergman J., Bergman S., J. Org. Chem., 50, 1246-1255 (1985).

10) Yao H., Liao Z. X., Wu Q., Lei G. Q., Liu Z. J., Chen D. F., Chen J. K., Zhou T. S., Chem. Pharm. Bull., 54, 133-135 (2006).

11) Hara S., Okabe H., Mihashi K., Chem. Pharm. Bull., 34, 1843-1844 (1986).

12) Yu D. Q., Yang J. S., "Handbook of Analytical Chemistry (VII)," Chemical Industry Press, Beijing, China, 1999, p. 902.

13) Sheu J. R., Cardiovasc. Drug Rev., 17, 235-237 (1999). 